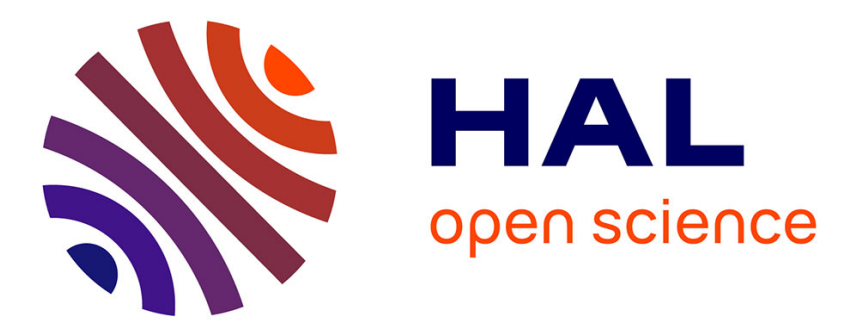

\title{
Cytological analysis of hybrids between Papaver somniferum L. and Papaver bracteatum lindl.; phylogenetic relationships between the two species
}

Axel Espinasse, Francoise F. Dosba

\section{- To cite this version:}

Axel Espinasse, Francoise F. Dosba. Cytological analysis of hybrids between Papaver somniferum L. and Papaver bracteatum lindl.; phylogenetic relationships between the two species. Agronomie, 1982, 2 (3), pp.281-286. hal-02725259

HAL Id: hal-02725259

https://hal.inrae.fr/hal-02725259

Submitted on 2 Jun 2020

HAL is a multi-disciplinary open access archive for the deposit and dissemination of scientific research documents, whether they are published or not. The documents may come from teaching and research institutions in France or abroad, or from public or private research centers.
L'archive ouverte pluridisciplinaire HAL, est destinée au dépôt et à la diffusion de documents scientifiques de niveau recherche, publiés ou non, émanant des établissements d'enseignement et de recherche français ou étrangers, des laboratoires publics ou privés. 


\title{
Cytological analysis of hybrids between Papaver somniferum L. and Papaver bracteatum Lindl.; phylogenetic relationships between the two species
}

\author{
Anne ESPINASSE \& Françoise DOSBA
}

I.N.R.A., Station d'Amélioration des Plantes, Centre de Recherches de Rennes B.P. 29, F35650 Le Rheu

\section{SUMMARY \\ Papaver, \\ P. somniferum $L$. \\ P. bracteatum Lindl. Interspecific hybrids, Meiotic analysis, Phylogenetic relation- ships.}

\begin{abstract}
The meiotic behaviour of $\mathrm{F}_{1}$ hybrids between Papaver somniferum L. $(2 \mathrm{n}=22)$ and Papaver bracteatum Lindl. $(2 \mathrm{n}=14)$ and of plants backcrossed to $P$. somniferum $(2 \mathrm{n}=29)$ is described (tables 1 and 2$)$. Mathematical methods of meiotic analysis [as developed by ALONSO \& KIMBER (1981) on assumptions of relative affinities between the genomes present in hybrids and of a mean arm-pairing frequency] have been used to investigate this observed behaviour. Although these methods of meiotic analysis may be criticized, first evidence has been obtained that the basic number seven of most Papaver species results from an amphiploid between two diploid species with basic numbers of four and three respectively as once suggested by SIGIURA (1940). Further it appears most likely that $P$. somniferum is a second amphiploid between a sevenchromosome species and a four-chromosome species unrelated to the first one. The practical use of $F_{1}$ hybrids between $P$. somniferum and $P$. bracteatum can be deduced from their meiotic behaviour.
\end{abstract}

\section{RÉSUMÉ}

Papaver,

P. somniferum,

P. bracteatum Lindl., Hybrides interspécifiques,

Analyse méiotique,

Relations phylogénétiques.
Analyse cytogénétique des hybrides entre Papaver somniferum L. et P. bracteatum Lindl. Relations phylogénétiques entre les deux espèces.

Le comportement méiotique des hybrides $\mathrm{F}_{1}$ entre Papaver somniferum $\mathrm{L}$. $(2 \mathrm{n}=22)$ et Papaver bracteatum Lindl. $(2 \mathrm{n}=14)$ et des plantes $\mathrm{RC}-1(2 \mathrm{n}=29)$ issues de rétrocroisements par $P$. somniferum sont décrits (tabl. 1 et 2). Les méthodes d'analyse de la méiose telles qu'elles furent développées par ALONSO \& KimbER (1981) à partir de la définition de c, la fréquence moyenne d'appariement d'un bras chromosomique, de $\mathrm{x}$, l'affinité relative entre les deux génômes les plus proches, et de y, l'affinité relative entre deux génomes plus éloignés, ont été utilisées pour interpréter les comportements méiotiques observés. Bien que ces méthodes prêtent à quelques critiques, on a ainsi obtenu les premières indications de l'origine amphiploïde du nombre de base sept chez $P$. bracteatum à partir de deux espèces diploïdes ayant respectivement trois et quatre pour nombre de base, ainsi que l'avait suggéré SIGIURA (1940). De plus, il semble se confirmer que $P$. somniferum soit un second amphiplö̈de entre une espèce à nombre de base sept et une espèce à nombre de base quatre qui ne serait pas apparentée à la première. L'utilisation pratique des hybrides $\mathrm{F}_{1}$ entre $P$. somniferum et $P$. bracteatum se déduit de l'étude de leurs comportements méiotiques.

\section{INTRODUCTION}

Three basic numbers, seven, six and eleven are encountered in the genus Papaver although both basic numbers six and eleven are rare. The occurrence of these three basic numbers in the same genus has been tentatively explained by SIGIURA (1940) on the hypothesis that the species with a basic number seven, for example $P$. bracteatum, could have been derived from an amphiploid between species of Chelidoneae $(\mathrm{x}=3)$ and of Corydaleae $(\mathrm{x}=4)$, both of which are closely related to the genus Papaver; besides the basic number six could be derived from seven by fusion of two chromosomes and SIGIURA (1940) has reported observing a longer chromosome in $P$. pavonium, a species with a basic number of six. However, no cytogenetic observations were made to confirm or invalidate this assumption. An allopolyploid origin of the basic number eleven of $P$. somniferum was suggested by YASUI (1937) and later by GROVER \& MALIK (1969).

The interest of Papaver species lies in their alkaloid compounds. $P$. bracteatum accumulates thebaine in its capsules, 1 to $4 \%$ of the dry matter ; thebaine is the precursor of codeine in the now-well established alkaloid biosynthetic pathway (PoIsson, 1974 ; Mourange \& CosTES, 1978). This species when fed with radioactive codeine fails to produce morphine (HoDGES et al., 1977) and thus apparently lacks the two enzymes required to transform thebaine into codeine and codeine into morphine. On the contrary, $P$. somniferum yields morphine, up to $1 \%$ of dry matter in the capsules of the best breeding strains. In view of the increasing demand for codeine, so far manufactured from morphine, it would appear logical to attempt to modify the morphinan biosynthetic pathway so that direct production of codeine occurs. Though this is a possible way, 
mutagenesis has not been assessed. A poppy yielding high quantities of codeine might also be obtained if it were possible to introduce alien $P$. somniferum gene (s) into $P$. bracteatum. Which of these ways is the most efficient way should become clear from study of the meiotic behaviour of $F_{1}$ hybrids between the two species and of the offspring from backcrosses to either parents. Further, the hybrids between $P$. somniferum $(2 \mathrm{n}=22)$ and $P$. bracteatum $(2 \mathrm{n}=14)$ provide a good opportunity to get information on the phylogenetic relations between the species.

\section{MATERIALS AND METHODS}

Breeding strains in the 7 th or 8 th year of self-fertilization of $P$. somniferum were used as one of the parents in the hybrids investigated.

The forms of $P$. bracteatum employed belonged to a wild population from Iran, and because this species is allogamous, the population is highly heterozygous.

Reciprocal crosses were produced and grown with additional light in the greenhouse, at temperatures of $10^{\circ} \mathrm{C}$ at night and $22^{\circ} \mathrm{C}$ during the day.

Chromosome counts were made on root tips using classical methods.

Meiosis was observed in pollen mother cells. Stamens were collected when the anthers were approximately $2 \mathrm{~mm}$ long and fixed for 48-72 hours in Carnoy fixative. They were rinsed in $90 \%$ alcohol and stored in $70 \%$ alcohol until ready for observation. The stamens were squashed and stained in aceto carmine with ion perchloride with heat and then mounted in dilute acetic acid $(45 \%)$.

The analysis of meiosis established by ALONSO \& KIMBER (1981) for triploid hybrids gives some first evidence about relationships between species. It was used on the partial pairing data of $F_{1}$ hybrids taken to be constituted of three genomes of four chromosomes and two genomes of three chromosomes. Backcrosses to $P$. somniferum were assumed to be composed of five genomes of four chromosomes and three genomes of three chromosomes; a linear combination of the method for triploid hybrids and of a similar method for pentaploid hybrids (ESPINASSE \& KIMBER, in press) was used on the pairing data. Both methods are described elsewhere (ESPINASSE, 1982).

\section{RESULTS AND DISCUSSION}

\section{A. Cytogenetic observations}

Seeds were produced in $60 \%$ of the crosses with $P$. somniferum as the female parent and $45 \%$ with $P$. bracteatum as the female. Not all of the seeds germinated and some of the young plants died after producing two or three redcolored leaves.

The hybrids were roughly morphologically similar irrespective of the direction of the cross. They all had 18 somatic chromosomes and were extremely sterile with nearly all the pollen grains, stained by «Alexander reagent », devoid of nucleus and collapsed. Female sterility was also high. Backcrosses to either parent produced not more than 15 seeds, which must be compared to an average seed yield of several thousands in each species.

All the backcrosses to $P$. bracteatum failed to grow, but three plants resulting from the backcrosses to $P$. somniferum were obtained; two of these resulted from the same pollination. Each of these BC-1 plants had 29 somatic chromosomes, presumably having received an unreduced gamete from the female parent.
Meiosis was examined in $17 \mathrm{~F}_{1}$ hybrids and in the parents (table 1 ). The accessions of $P$. somniferum and the population of $P$. bracteatum regularly made eleven and seven bivalents respectively at first metaphase. In the $F_{1}$ hybrids, the univalent number varied from 6 to 18 while the bivalent and trivalent numbers increased from 0 to 6 and from 0 to 2 respectively. Some quadrivalents and pentavalents were observed. The two most common cellular types were, respectively, 14 univalents and 2 bivalents, 12 univalents and 3 bivalents. But the mean numbers of each meiotic figure and the ranges varied from one hybrid to another (table 1). It appeared that the differences between the two extreme means, in the case of each meiotic figure, were statistically significant using variance analysis for variable stocks (KRAMER, 1956). Hybrid 10 was entirely separated from the group of the others by this test. Since this hybrid has the same origin as hybrids 11 and 12, the highly significant difference may be due to the relatively low number of cells analyzed. However, when hybrid 10 was excluded, the differences between the means numbers of univalents, rod bivalents and trivalents remained significant (5\%) but not the others.

Meiosis was observed in two BC-1 plants. In both almost all the cells had 11 bivalents and 7 univalents, but trivalents occurred at a low frequency (table 2). These results would be expected if the two haploid genomes of $P$. somniferum, which were from the same strain used first as female parent and later as male parent, paired together and the seven chromosomes of $P$. bracteatum remained unpaired in most of the cases. No statistical significance was observed for the BC-1 plants.

The different meiotic behaviour of the various $F_{1}$ hybrids between $P$. somniferum and $P$. bracteatum may be ascribed to the fact that they involved several different inbred lines of $P$. somniferum and a heterozygous population of $P$. bracteatum. Therefore, it was assumed that the differences recognized by the analysis of variance are only due to the heterogeneous origin of both parents and have no other biological meaning. An average meiotic behavior of the $F_{1}$ hybrids was calculated from the 1921 observed cells: 13.80 univalents +1.51 rod bivalents +0.47 ring bivalents +0.071 trivalents +0.004 multivalents (including five quadrivalents and two pentavalents).

The calculation of this meiotic behaviour may be incorrect; nevertheless it is clear that pairing occurs in the hybrids between $P$. somniferum and $P$. bracteatum. It may be allosyndetic or autosyndetic, this later origin being supported by the supposed distant relationship between the two species: their basic chromosome numbers are different, they are derived from widely separate locations and the first is mainly autogamous while the second is strictly allogamous.

50 to $70 \%$ of the observed rod bivalents were heteromorphic in the $F_{1}$ 's (ESPINASSE, 1980). Since the chromosomes of $P$. bracteatum are smaller than those of $P$. somniferum, these chromosomes must indicate allosyndetic pairing. Further, the presence of trivalents in $\mathrm{BC}-1$ plants appears to be related in most cases to the association of one chromosome of $P$. bracteatum with the two homologs of $P$. somniferum and thus again must represent allosyndetic pairing. The fact that this pairing takes place while two homologous genomes are present must indicate an even greater allosyndetic pairing in $F_{1}$ 's. However the remaining bivalents in $F_{1}$ 's may be allosyndetic as well as autosyndetic. Thus both allosyndetic and autosyndetic pairing would appear to occur in the $\mathrm{F}_{1}$ 's. 
TABLE 1

Observed mean numbers (1) and ranges (2) of each meiotic figure in $\mathrm{P}$. somniferum, $\mathrm{P}$. bracteatum and $F_{1}$ hybrids between these two species. Nombre moyen (1) et valeurs extrêmes (2) observés pour chaque figure méiotique chez $\mathrm{P}$. somniferum, $\mathrm{P}$. bracteatum et les hybrides $F_{l}$ entre les 2 espèces.

\begin{tabular}{|c|c|c|c|c|c|c|}
\hline $\begin{array}{l}\text { Designation } \\
\text { of plant }\end{array}$ & $\begin{array}{c}\text { Number } \\
\text { cells }\end{array}$ & univalents & $\begin{array}{c}\text { rod } \\
\text { bivalents }\end{array}$ & $\begin{array}{c}\text { ring } \\
\text { bivalents }\end{array}$ & trivalents & multivalents \\
\hline P. somniferum & 1039 & & $\begin{array}{l}\text { (1) } 0.51 \\
\text { (2) } 0-7\end{array}$ & $\begin{array}{c}10.49 \\
4-11\end{array}$ & & \\
\hline P. bracteatum & 398 & & $\begin{array}{c}0.61 \\
0-4\end{array}$ & $\begin{array}{c}6.39 \\
3-7\end{array}$ & & \\
\hline \multicolumn{7}{|l|}{$F_{1}$ hybrids } \\
\hline 10 & 56 & $\begin{array}{r}11.02 \\
8.18\end{array}$ & $\begin{array}{l}2.54 \\
0-5\end{array}$ & $\begin{array}{c}0.34 \\
0-2\end{array}$ & $\begin{array}{c}0.34 \\
0-2\end{array}$ & (a) $\begin{array}{l}0.05 \\
0-1\end{array}$ \\
\hline 11 & 82 & $\begin{array}{r}12.37 \\
7-16\end{array}$ & $\begin{array}{c}2.38 \\
0-4\end{array}$ & $\begin{array}{c}0.15 \\
0-1\end{array}$ & $\begin{array}{c}0.20 \\
0-2\end{array}$ & \\
\hline 3 & 90 & $\begin{array}{r}12.44 \\
7-18\end{array}$ & $\begin{array}{l}1.16 \\
0-3\end{array}$ & $\begin{array}{c}1.49 \\
0-4\end{array}$ & $\begin{array}{c}0.09 \\
0-1\end{array}$ & \\
\hline 5 & 105 & $\begin{array}{r}12.93 \\
8-18\end{array}$ & $\begin{array}{l}2.21 \\
0-5\end{array}$ & $\begin{array}{c}0.13 \\
0-2\end{array}$ & $\begin{array}{c}0.11 \\
0-2\end{array}$ & (a) 0.01 \\
\hline 8 & 135 & $\begin{array}{r}13.02 \\
6-18\end{array}$ & $\begin{array}{l}1.56 \\
0-6\end{array}$ & $\begin{array}{c}0.72 \\
0-3\end{array}$ & $\begin{array}{l}0.13 \\
0-1\end{array}$ & (b) $\begin{array}{c}0.01 \\
0-1\end{array}$ \\
\hline 15 & 110 & $\begin{array}{r}13.05 \\
8-18\end{array}$ & $\begin{array}{c}1.33 \\
0-4\end{array}$ & $\begin{array}{l}1.00 \\
0-4\end{array}$ & $\begin{array}{c}0.09 \\
0-2\end{array}$ & \\
\hline 14 & 151 & $\begin{array}{r}13-29 \\
8-18\end{array}$ & $\begin{array}{c}1.79 \\
0-3\end{array}$ & $\begin{array}{c}0.52 \\
0-3\end{array}$ & $\begin{array}{l}0.03 \\
0-1\end{array}$ & \\
\hline 12 & 124 & $\begin{array}{r}13.81 \\
8-18\end{array}$ & $\begin{array}{c}1.91 \\
0-5\end{array}$ & $\begin{array}{c}0.06 \\
0-2\end{array}$ & $\begin{array}{c}0.09 \\
0-1\end{array}$ & \\
\hline 6 & 61 & $\begin{array}{r}14.10 \\
9-18\end{array}$ & $\begin{array}{l}1.59 \\
0-4\end{array}$ & 0.20 & 0.07 & (a) $(0.03)$ \\
\hline 2 & 139 & 14.17 & 1.68 & 0.13 & 0.07 & \\
\hline & & $10-18$ & $0-4$ & $0-2$ & $0-1$ & \\
\hline 16 & 118 & $\begin{array}{l}14.22 \\
10-18\end{array}$ & $\begin{array}{c}0.95 \\
0-3\end{array}$ & $\begin{array}{c}0.84 \\
0-3\end{array}$ & $\begin{array}{c}0.06 \\
0-1\end{array}$ & \\
\hline (c) 20 & 169 & $\begin{array}{r}14.23 \\
8-18\end{array}$ & $\begin{array}{l}1.43 \\
0-5\end{array}$ & $\begin{array}{c}0.44 \\
0-4\end{array}$ & $\begin{array}{c}0.01 \\
0-1\end{array}$ & \\
\hline 7 & 103 & $\begin{array}{r}14.33 \\
6-18\end{array}$ & $\begin{array}{l}1.33 \\
0-5\end{array}$ & $\begin{array}{c}0.40 \\
0-3\end{array}$ & $\begin{array}{c}0.05 \\
0-1\end{array}$ & (b) $\begin{array}{c}0.01 \\
0-1\end{array}$ \\
\hline 4 & 130 & $\begin{array}{l}14.71 \\
10-18\end{array}$ & $\begin{array}{l}1.35 \\
0-4\end{array}$ & $\begin{array}{c}0.25 \\
0-2\end{array}$ & $\begin{array}{c}0.03 \\
0-1\end{array}$ & \\
\hline 18 & 110 & $\begin{array}{r}14.76 \\
9-18\end{array}$ & $\begin{array}{c}0.76 \\
0-3\end{array}$ & $\begin{array}{c}0.77 \\
0-3\end{array}$ & $\begin{array}{c}0.05 \\
0-1\end{array}$ & \\
\hline 19 & 130 & $\begin{array}{l}14.80 \\
10-18\end{array}$ & $\begin{array}{c}1.16 \\
0-4\end{array}$ & $\begin{array}{c}0.32 \\
0-4\end{array}$ & $\begin{array}{c}0.05 \\
0-1\end{array}$ & \\
\hline 17 & 108 & $\begin{array}{l}10-18 \\
15.21 \\
10-18\end{array}$ & $\begin{array}{c}0-4 \\
1.15 \\
0-3\end{array}$ & $\begin{array}{c}0.4 \\
0.20 \\
0-2\end{array}$ & $\begin{array}{c}0-1 \\
0.01 \\
0-1\end{array}$ & \\
\hline
\end{tabular}

(a) one or two quadrivalents.

(b) one pentavalent

(c) hybrid 20 had $P$. bracteatum as female parent.

TABLE 2

Mean meiotic behaviour of $B C-1$ plants.

Comportement méiotique moyen des plantes $R C-1$.

\begin{tabular}{cccccc}
\hline \hline $\begin{array}{c}\text { Designation } \\
\text { of plants }\end{array}$ & Number of cells & univalents & rod bivalents & ring bivalents & trivalents \\
\hline \multirow{2}{*}{1} & 110 & $7(1)$ & 1.63 & 9.34 & 0.019 \\
2 & 186 & $7-8(2)$ & $0-5$ & $6-11$ & $0-1$ \\
& & 7 & 2.78 & 0.21 & 0.005 \\
& & $7-8$ & $0-8$ & $3-11$ & $0-1$ \\
\hline
\end{tabular}

(1) mean number (nombres moyens).

(2) range (valcurs extrêmes).

\section{B. Mathematical analysis of meiosis}

The relatively high frequency of multivalents $(1 \%$ of cells with 1 trivalent) in the $F_{1}$ hybrids described in this contribu- tion may be ascribed to translocation. But, more likely, multivalents are due to the alloploid origin of $P$. somniferum and provide the first real evidence of the assumption once made by YASUI (1937) and by Grover \& MALIK 
(1969): $11=7+4$. If the amphiploid origin of the basic number 7 (SIGIURA, 1940) is accepted, the $P$. somniferum basic number 11 results from a second hybridization: $11=(4+3)+4$. Whether the additional four chromosomes are identical or not to the first cannot be determined.

These phylogenic assumptions result in the following genomic structures : $P$. bracteatum has one genome of four chromosomes and one genome of three chromosomes from two diploid ancesters; $P$. somniferum has one genome of three chromosomes and two genomes of four chromosomes from two or more diploid ancesters ; the $F_{1}$ hybrids have two genomes of three chromosomes and three of four chromosomes.

As it was further assumed that the two genomes of three chromosomes are homeologous as well as the three genomes of four chromosomes, the $F_{1}$ hybrids have three groups of two homeologs and four groups of three homeologs. Pairing between the two homeologs in each of the former three groups clearly cannot involve competition and thus the expected bivalent and univalent frequencies may be calculated on the assumption of random pairing and of $c$, the mean arm pairing frequency (method described by DRISCOLl et al., 1979). These calculated bivalent and univalent frequencies $(1.02 ; 3.95$ respectively) were substracted from the observed frequencies; the remaining chromosome pairing was assumed then to occur strictly between the three homeologs within each group of three chromosomes. These modified data were compared to the expected ones following the method established by ALONSO \& KIMBER (1981) for triploid hybrids. The expected frequencies of each meiotic figure were derived from definitions of $\mathrm{c}$, of $\mathrm{x}$, the relative affinity of the two most closely related genomes, and of $y$, the relative affinity of any two more distantly related genomes (fig. 1b). Using a least square method, the optimum value of $x$ was calculated and used as a measure of the relationship between species.

The $F_{1}$ hybrids could be divided into three classes on the basis of this calculation (table 3 ). The first two classes make up the majority, having a calculated optimum value of $x$ equal to or greater than one, but either with a good or a bad fit.

Two explanations of a value of $\mathbf{x}$ greater than one are possible :

i) the pairing data used are partial and, as they resulted from calculations, they might be slightly erroneous;

ii) the value of $c$ was assumed to be the same for the chromosomes of the three genomes of four chromosomes and for the chromosomes of the two genomes of three chromosomes, which may not be true. No other evaluation

Figure 1

Schematic representations of models $2: 2: 1$ and $2: 1$ for pentaploid and triploid hybrids.

Représentation schématique des modèles $2: 2: 1$ et $2: 1$ pour les hybrides pentaploides et triploïdes.

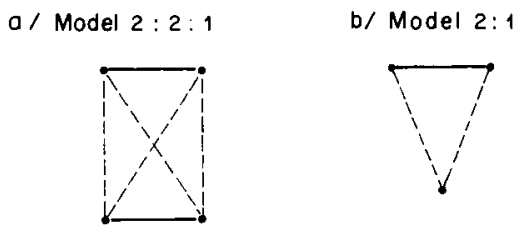

The relative affinity between the two genomes is $X$ The relative affinity between the two genomes is $Y$
TABLE 3

Meiotic analysis of $F_{l}$ hybrids by the triploid method of ALONSO and KIMBER (1981).

Analyse de la méiose des hybrides $F_{1}$ selon la méthode établie pour les hybrides triploides par ALONSO \& KIMBER (in press).

\begin{tabular}{ccccl}
\hline $\begin{array}{c}\text { Number of } \\
\mathbf{F}_{1} \text { hybrids }\end{array}$ & $\mathrm{X}$ & $\mathrm{Y}$ & $\begin{array}{c}\text { ranges of } \\
\mathrm{C}\end{array}$ & \multicolumn{1}{c}{ fitness } \\
\hline 4 & 0.500 & 0.500 & $0,161-0,279$ & good : $<0,1$ \\
8 & $\geqslant 1$ & 0 & $0,112-0,206$ & good $: 0,1$ à 0,4 \\
5 & $\geqslant 1$ & 0 & $0,183-0,323$ & bad : $>1$ \\
\hline
\end{tabular}

$\mathrm{X}$ : relative affinity between the most close genomes; optimum value.

$Y$ : relative affinity between the least close genomes; optimum value.

$\mathrm{C}$ : mean chromosome arm-pairing frequency; observed ranges. Fitness: sum of squares of differences between observed and expected frequencies for the optimum values of $\mathrm{X}$ and $\mathrm{Y}$.

of $\mathrm{c}$ is possible since the individual chromosome pairing in the hybrids cannot be identified.

The use of only two variables $(x, y)$ instead of three to define the three distances between the three genomes of four chromosomes is the most likely cause of the bad fit observed in same case. Even then the 2:1 model (two genomes more closely related than they both are to the third) gives a better representation of the true relationships between the three genomes than the random pairing model.

The third group of hybrids consisted of four plants, three of which were in one hybrid combination with an optimum value of $\mathrm{x}$ equal to 0,5 , thus indicating random pairing between the three homeologs inside each of the four groups.

These three groups do not fit the ones that could be deduced from the analysis of variance previously reported (ESPINASSE, 1980).

The separation of the hybrids into three groups on the basis of these calculations may be accounted for in at least two possible ways. First, as mentioned earlier, it is possible that random pairing and preferential pairing situations may be related to the heterogeneous population of $P$. bracteatum or to the different karyotypes known to exist in various $P$. somniferum accessions (GROVER \& MALIK, 1969). The cstablishment of translocations and inversions in $P$. somniferum (HRISHI, 1960) would cause differentiation between the homeologous chromosomes of the three genomes of four chromosomes (two from $P$. somniferum and one from $P$. bracteatum) so that they would have different relative affinity from one $F_{1}$ hybrid to another. Inversion bridges were observed in some $F_{1}$ hybrids at the first meiotic metaphase. Second, the mean arm pairing frequency (c), may not be the same for all chromosomes, as was assumed. If it were so, the calculations based upon the assumption of equality would be incorrect, while, for the low values of $c$, the differences between the expected calculations of meiotic figure frequency for each value of $x$ are not very substantial and consequently any small variation may lead to an erroneous optimum value of $x$. However, it is not possible to determine whether $\mathrm{c}$ is the same for the chromosomes of the three groups of two homeologs as for the chromosomes of the four groups of three homeologs.

Under the previous genomic assumptions, the BC-1 plants would have five genomes of four chromosomes and three genomes of three chromosomes. Four of the five genomes of four chromosomes are received from $P$. somni- 
TABLE 4

Meiotic analysis of $B C 1$ plants by the combination of pentaploid model $2: 2: 1$ and triploid model $2: 1$.

Analyse de la méiose des plants $R C 1$ par une combinaison des modèles pentaploïde $2: 2: 1$ et triploïde $2: 1$.

\begin{tabular}{l}
$\begin{array}{l}\text { Designation } \\
\text { of plants }\end{array}$ \\
\hline 1
\end{tabular}

ferum and therefore are homologous two by two ; two of the three genomes of three chromosomes are homologous for the same reason. If this arrangement of chromosomes were correct, the five genomes of four would fit the $2: 2: 1$ model for pentaploid hybrids (fig. $1 a$ ) with a basic number of four and the three genomes of three would fit the $2: 1$ model for triploid hybrids (fig. $1 b$ ) with a basic number of three. The observed data for the $\mathrm{BC}-1$ plants have been compared to the expected ones calculated by the linear combination of the calculations of the $2: 2: 1$ model (ESPINASSE \& KIMBER, in press) and of the $2: 1$ model made for a basic number of four and three respectively (table 4).

Because of homology between $P$. somniferum chromosomes, the optimum values of $\mathrm{x}$ in both models were anticipated and thus were observed to be close to 1 , with a good fit and a high value of $\mathrm{c}$. This leads to acceptance of the assumed chromosome arrangement in the $\mathrm{BC}-1$ plants and consequently in the $F_{1}$ hybrids, which were based on the same assumptions. This further, a posteriori, justifies the use of a linear combination of models derived for different ploidy levels for both BC-1 plants and $\mathrm{F}_{1}$ hybrids and the calculation of the mean arm pairing frequency (c) based on the assumption that it was the same for all genomes.

Because of the low value of the mean arm pairing frequency, pairing occurs only between homeologs and consequently the additional four chromosomes of $P$. somniferum are not the result of partial autopolyploidy.

In most hybrids between $P$. somniferum and $P$. bracteatum two four-chromosomes genomes out of the three present are more closely related to each other than they are to the third. The two from $P$. somniferum have existed together for some time and recombination between them may have taken place before any genetic control of meiosis has been established. So preferential pairing would be due to translocation and recombination and would have occurred between $P$. somniferum homeologs. However, there is evidence that allosyndetic pairing occurs even in the BC-1 plants. Since $P$. somniferum appears to be a second hybrid between a seven chromosomes species and a four chromosomes species it may be argued that the seven-chromosome of $P$. somniferum pair preferentially with the seven chromosomes of $P$. bracteatum as they would be more closely related to them than to the other four chromosomes of $P$. somniferum. Pairing would then be mainly allosyndetic. Both types of pairing surely occur but no definite conclusions can yet be drawn from our results.

\section{CONCLUSION}

Using the methods of meiotic analysis developped by ALONSO \& KIMBER (1981) for triploid hybrids and by ESPINASSE \& KIMBER (in press) for pentaploid hybrids, the observed meiotic pairing in $F_{1}$ hybrids between $P$. somniferum and $P$. bracteatum and in the $\mathrm{BC}-1$ plants (backcrosses to $P$. somniferum) appears to be best explained by assuming that the former hybrids have four groups of three homeologous chromosomes and three groups of two homeologous chromosomes and the latter plants are composed of five groups of four chromosomes and three groups of three chromosomes. However, it seems that more precise expectations could be calculated using a maximum likelihood method or a least square method weighted by the matrix of variances and covariances (AZAIS et al., 1982). New equations are presently being derived and the use of these improved methods on the pairing data given in this contribution will be reported later.

Nevertheless, these results represent the first meiotic evidence that the basic number seven in the genus Papaver may have developed as a consequence of a hybridization between two diploid species with a basic number of three and four respectively and furthermore that the basic number eleven of $P$. somniferum has probably derived from a second hybridization between a seven-chromosome species and a four-chromosome species. Because of the low value of the mean arm pairing frequency, this second four-chromosome species would not be related to the first one. The meiotic behaviour of the haploids of $P$. somniferum might supply additional arguments for this conclusion.

Cytogenetic observations and mathematical analysis of meiosis both provide evidence that pairing is partly allosyndetic. However the frequency of this allosyndetic pairing is very low and, thus, the classical use of $F_{1}$ hybrids to introduce alien genes from one species to another would appear to be inefficient to bring about the introgression of alien genes from $P$. somniferum into $P$. bracteatum. This would require the use of the appropriate disomic addition lines of $P$. somniferum into $P$. bracteatum, coupled with the use of methods promoting recombinations between homeologous chromosomes such as pollen irradiation. This conclusion is of interest for the practical purpose of breeding a poppy yielding high quantities of codeine.

Reçu le 30 mars 1981. Accepté le 13 novembre 1981.

\section{ACKNOWLEDGEMENTS}

The authors wish to thank Dr. G. Kimber and Dr. L. C. Alonso for the personal communication of their mathematical method for meiotic analysis.

We also would like to thank Dr. E. R. Sears and Dr. G. KIMBER for reading this manuscript to get it ready for its final form. 


\section{REFERENCES}

Alonso L. C., Kimber G., 1981. The analysis of meiosis in hybrids. II. Triploid hybrids. Can. J. Genet. Cytol., 23 (2), 221-234.

Azais J. M., Denis J. B., Douaire G., 1982. Analyse statistique de configurations méiotiques dans le cas de triploïdes. Agronomie, 2 , (3), 281-286.

Driscoll C. J., Bielig L. M., Darvey N. L., 1979. An analysis of frequencies of chromosome configurations in wheat and wheat hybrids. Genetics, 91, 755-767.

Espinasse A., 1980. Les potentialités en thébaïne, codéine, morphine offertes par les espèces du genre Papaver et quelques-uns de leurs hybrides. Thèse de Docteur-Ingénieur, Rennes, $122 \mathrm{p}$

Espinasse A., Kimber G., 1981. The analysis of meiosis in hybrids. IV. Pentaploid hybrids. Can. J. Genet. Cytol., in press.

Grover I. S., Malik C. P., 1969. Karyological studies in some Papaver species. Genet. iber., 21, (1-2), 105-113.

Hodges C. C., Horn J. S., Rapoport H., 1977. Morphinan alkaloids in Papaver bracteatum biosynthesis and fate. Phytochemistry, 16, 1939-1962.
Hrishi N. J., 1960. Cytological studies on Papaver somniferum L. and Papaver setigerum D.C. and their hybrid. Genetica, 31, 1-2, 130 .

Kimber G., Alonso L. C., 1981. The analysis of meiosis in hybrids. I. Ancuploid hybrid. Can. J. Genet. Cytol., 23 (2), 209-219.

Kramer C. Y., 1956. Extension of multiple range tests to group means with unequal numbers of replications. Biometrics, 12, 307310

Mourange A., Costes C., 1978. Mise au point bibliographique sur la biosynthèse de la morphine et des autres alcaloüdes morphinanes. Ann. Technol. agric., 27 (3), 715-737.

Poisson J., 1974. La biosynthèse des alcaloïdes. Ann. Pharm. Fr., 32 (1), 69-90

Sigiura T., 1940. Chromosome studies on Papaveraceae with special reference to the phylogeny. Cytologia, 10, 558-576.

Yasui K., 1937. Cytogenetic studies in artifically raised interspecific hybrids of Papaver. VII. P. somniferum L. $\times P$. bracteata Lindl. Cytologia, 7, 535-563. 